\title{
Modeling of Partition Method for Phase Coupling Terms in Large Eddy Simulation of Spray Combustion
}

\author{
Yuya $\mathrm{BABA}^{* 2}$ and Fumiteru AKAMATSU \\ ${ }^{* 2}$ Department of Mechanical Engineering, Osaka University, \\ 2-1 Yamada-Oka, Suita-shi, Osaka, 565-0871 Japan
}

\begin{abstract}
Large eddy simulation of spray combustion was performed with Dynamic SGS model for compressible turbulence. SGS model of combustion reaction was also introduced to take account for contribution of SGS components to combustion reaction rate term. The SGS models were evaluated by comparing results of LES with DNS, which governing equations were not filtered and which had high resolution. A partition method for phase coupling terms and two types methods for partition of gaseous phase variables were applied to compare the results of simulations which have different grid resolutions. The results of LES were greatly improved with the increase of spatial resolution and the contribution of SGS stress decreased with increase of the resolution. However, LES with coarse resolution also could show good agreement with the DNS, in spite of the low resolution. On the other hand, the SGS diffusivity increased with the increase of spatial resolution. From the above results, we could conclude that the proposed partition method for phase coupling terms and partition type a were appropriate for LES of spray combustion.
\end{abstract}

Key Words : Liquid Fuel, Combustion, Multi-phase Flow, Large Eddy Simulation, Grid Resolution, SGS Contributions, Phase Coupling Term

\section{1. 緒言}

LES (Large eddy simulation) は解像できない SGS (Subgrid-scale) 成分を付加項としてモデル化すること で DNS (Direct numerical simulation) で計算できる空 間スケールよりも大きな空間スケールを計算可能とす る数值計算法である．燃焼分野においても LES の適用 例は多く見られるようになったが，計算負荷を軽減さ せる目的から, 混合分率とスカラー消散率を用いて火 炎を記述し，非圧縮性流体解析をそのまま流用するこ とが多い.しかしながら噴霧燃焼流は燃焼反応によっ て引き起こされる数多くの素過程を含む複雑な流れで あるので, 大幅なモデル化を行った場合，より複雑な 問題に対応することができなくなる.このため, 複雑 な問題である噴霧燃焼流に非圧縮性流体解析を流用す ることは好ましくなく，本来は反応性および圧縮性流 体を前提としたDNS の支配方程式を直接 LES に拡張 する必要がある.

混相燃焼流の LES は末だ例が少ない。これまでの

* 原稿受付 2005 年 7 月 19 日.

*1 正員, 大阪大学大学院工学研究科(五565-0871 吹田市山田 丘 2-1).

E-mail : babay@ combu.mech.eng.osaka-u.ac.jp
研究にはGlaze ら ${ }^{(1)}$, Kurose ら ${ }^{(2)}$ の研究があげられる が，モデル化に伴う問題点については未検討である. 一方で, DNS の支配方程式をフィルター化し, 噴霧燃 焼流の LES に用いた場合の SGS 成分の影響は未知で ある. LES では格子解像度がどのように変化しても, 妥当な結果を得ることができるはずであるが, SGS 成 分の影響が未知であるため, 格子解像度をどのように 設定すべきかは明確ではない，本稿ではまず，格子解 像度およびSGS 成分の影響と関係する可能性が高い 相間干涉項の割付け方法を提案し, 様々な格子解像度 でLESを行うことで提案した割付け方法の妥当性を 示すことを目的とする. また, SGS 成分の影響が割付 け方法および格子解像度によってどのように変化する かについての検討を行う.

\begin{tabular}{lllll} 
& & \multicolumn{2}{c}{ 記 } & \multicolumn{2}{c}{ 号 } \\
$\rho$ & 密度 & $c_{p}$ & 定圧比熱 \\
$u_{i}$ & 速度 & $c_{v}$ & 定積比熱 \\
$T$ & 温度 & $p$ & 圧力 \\
$\mu$ & 粘性係数 & $\lambda$ & 熱伝導率 \\
$R$ & 一般ガス定数 & $v_{i}$ & 液滴速度
\end{tabular}




$\begin{array}{llll}T_{d} & \text { 液滴温度 } & m_{d} & \text { 液滴質量 } \\ X_{i} & \text { 液滴位置の座標 } & D & \text { 液滴粒径 } \\ R e & \text { レイノルズ数 } & M & \text { マッハ数 } \\ P r & \text { プラントル数 } & S c & \text { シュミット数 } \\ N u & \text { ヌッセルト数 } & S h & \text { シャーウッド数 } \\ Y_{K} & \text { 化学種質量分率 } & W_{k} & \text { 分子量 } \\ V_{k, j} & \text { 拡散速度 } & h_{k} & \text { エンタルピー } \\ \omega_{k} & \text { 燃焼反応速度 } & \gamma & \text { 比熱比 }\end{array}$

\section{2. 数值計算法}

本稿では便宜上, フィルターをかけない流れを計算 する場合を DNS, フィルターをかけた流れを計算す る場合を LES と表記する.

2.1 気相の支配方程式 DNS では以下のフィル ターをかけない質量保存式, 圧縮性 Navier-Stokes 式, エネルギー保存式, 化学種の質量分率保存式を解く. エネルギー保存式は物性值を直接算出するために温度 表示としている ${ }^{(3)}$. また, 数値解法の都合上, 以下の 支配方程式は非保存形 (Non-conservative form) として いる.

$$
\begin{aligned}
& \frac{\partial \rho}{\partial t}+u_{j} \frac{\partial \rho}{\partial x_{j}}=-\rho \frac{\partial u_{j}}{\partial x_{j}}+S_{\rho} \\
& \rho \frac{\partial u_{i}}{\partial t}+\rho u_{j} \frac{\partial u_{i}}{\partial x_{j}}=-\frac{\partial p}{\partial x_{i}}+\frac{\partial \sigma_{i j}}{\partial x_{j}}+S_{u_{i}} \\
& \rho c_{v} \frac{\partial T}{\partial t}+\rho c_{v} u_{j} \frac{\partial T}{\partial x_{j}}=-p \frac{\partial u_{j}}{\partial x_{j}}+\frac{\partial}{\partial x_{j}}\left(\lambda \frac{\partial T}{\partial x_{j}}\right) \\
& +\sigma_{i j} \frac{\partial u_{i}}{\partial x_{j}}-\sum_{k=1}^{N}\left(c_{p, k} \frac{\partial T}{\partial x_{j}}+T R / W_{k} \frac{\partial}{\partial x_{j}}\right)\left(\rho Y_{k} V_{k, j}\right) \\
& +\sum_{k=1}^{N} \omega_{k}\left(T R / W_{k}-h_{k}\right)+S_{T} \\
& \rho \frac{\partial Y_{k}}{\partial t}+\rho u_{j} \frac{\partial Y_{k}}{\partial x_{j}}=-\frac{\partial\left(\rho Y_{k} V_{k, j}\right)}{\partial x_{j}}+\omega_{k}+S_{Y_{k}}
\end{aligned}
$$

ここでは化学種として $\mathrm{C}_{10} \mathrm{H}_{22}$ (デカン), $\mathrm{H}_{2} \mathrm{O}, \mathrm{CO}_{2}$, $\mathrm{O}_{2}$ および $\mathrm{N}_{2}$ を考慮する. 支配方程式中の輸送係数お よび熱力学物性は $\mathrm{CHEMKIN}^{(4)(5)}$ によって算出するこ とができる. 各保存式の右辺末項 $S$ は液相との間の相 間干渉項である． $\sigma_{i j}$ は粘性応力テンソルで,

$$
\sigma_{i j}=\mu\left(\frac{\partial u_{i}}{\partial x_{j}}+\frac{\partial u_{j}}{\partial x_{i}}\right)-\frac{2}{3} \mu \delta_{i j} \frac{\partial u_{i}}{\partial x_{j}}
$$

である. 以上の支配方程式の差分化には原則として 4 次精度中心差分法を用いる(6)(7). 保存形の支配方程式 にフィルターをかけることでLES で解く支配方程式 群が導かれ, SGS 項が現れる.ここではフィルター化
を施した後の方程式を非保存形に変形し, 支配的な項 のみを考慮した以下の式を解く.

$$
\begin{aligned}
& \frac{\partial \bar{\rho}}{\partial t}+\tilde{u_{j}} \frac{\partial \bar{\rho}}{\partial x_{j}}=-\bar{\rho} \frac{\partial \tilde{u}_{j}}{\partial x_{j}}+S_{\rho}, \\
& \bar{\rho} \frac{\partial \tilde{u}_{i}}{\partial t}+\bar{\rho} \tilde{u}_{j} \frac{\partial \tilde{u}_{i}}{\partial x_{j}}=-\frac{\partial \bar{p}}{\partial x_{i}}+\frac{\partial \tilde{\sigma}_{i j}}{\partial x_{j}}-\frac{\partial \tau_{i j}}{\partial x_{j}}+S_{u_{i}}, \\
& \bar{\rho} \overline{c_{v}} \frac{\partial \tilde{T}}{\partial t}+\bar{\rho} \overline{c_{v}} \tilde{u_{j}} \frac{\partial \tilde{T}}{\partial x_{j}}=-\bar{p} \frac{\partial \tilde{u}_{j}}{\partial x_{j}}+\frac{\partial}{\partial x_{j}}\left(\bar{\lambda} \frac{\partial \tilde{T}}{\partial x_{j}}\right) \\
& -\overline{c_{v}} \frac{\partial q_{j}}{\partial x_{j}}+\tilde{\sigma}_{i j} \frac{\partial \tilde{u}_{i}}{\partial x_{j}} \\
& -\sum_{k=1}^{N}\left(\bar{c}_{p, k} \frac{\partial \tilde{T}}{\partial x_{j}}+\tilde{T} R / W_{k} \frac{\partial}{\partial x_{j}}\right)\left(\bar{\rho} \tilde{Y}_{k} \bar{V}_{k, j}\right) \\
& +\sum_{k=1}^{N} \bar{\omega}_{k}\left(\tilde{T} R / W_{k}-\bar{h}_{k}\right)+S_{T},
\end{aligned}
$$

$\bar{\rho} \frac{\partial \tilde{Y}_{k}}{\partial t}+\bar{\rho} \tilde{u}_{j} \frac{\partial \tilde{Y}_{k}}{\partial x_{j}}=-\frac{\partial\left(\bar{\rho} \tilde{Y}_{k} \bar{V}_{k, j}\right)}{\partial x_{j}}-\frac{\partial d_{k, j}}{\partial x_{j}}+\bar{\omega}_{k}+S_{Y_{k}}$,

ここでーは空間フィルターをかけた值を示す. は Favre フィルターをかけた值を示しており, $\tilde{\phi}=\overline{\rho \phi} / \bar{\rho}$ で定 義される. $\tau_{i j}$ はSGS 応力, $q_{j}$ および $d_{k, j}$ はそれぞれ 温度, 化学種の SGS 拡散である. SGS 応力は Moin ら

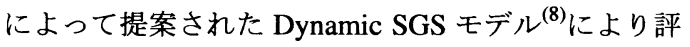
価する. 圧縮性流体の Dynamic SGS モデルではSGS 応力は次のように与えられる.

$$
\tau_{i j}-1 / 3 q^{2} \delta_{i j}=-2 \bar{\rho} C \Delta^{2}|\tilde{S}|\left(\tilde{S}_{i j}-1 / 3 \tilde{S}_{m m} \delta_{i j}\right)
$$

ここで $\tilde{S}_{i j}=1 / 2\left(\partial \tilde{u}_{i} / \partial x_{j}+\partial \tilde{u}_{j} / \partial x_{i}\right),|\tilde{S}|=\left(2 \tilde{S}_{i j} \tilde{S}_{i j}\right)^{1 / 2}$ であり, $\Delta$ はフィルター幅である. SGS モデルの導出 は非圧縮性流体の Dynamic モデルと同様で, Germano Identity $^{(9)}$ を導入して SGS 応力の算出できない項を消 去することで導出できる.

$C$ は Dynamic SGS モデルによって決定されるモデ ル定数で, Smagorinsky モデルの渦粘度の係数 $C_{e}$ とは $C=C_{e}^{2}$ という関係がある. $q^{2}$ はSGS 応力の等方性成 分であり，等方性成分の渦粘度の係数 $C_{I}$ から

$$
q^{2}=2 C_{l} \bar{\rho} \Delta^{2}|\tilde{S}|^{2}
$$

と計算される. 渦粘度の係数 $C$ と等方性成分の渦粘度 の係数 $C_{I}$ は

$$
\begin{aligned}
& C=\left\langle\left[\widehat{\bar{\rho} \tilde{u}_{i} \tilde{u}_{i}}-\widehat{\bar{\rho} \tilde{u}_{i}} \widehat{\bar{\rho} \tilde{u}_{j}} / \hat{\bar{\rho}}\right] \tilde{S}_{i j}-1 / 3 \tilde{S}_{m m}\left(\mathscr{T}_{j j}-\hat{\tau}_{j j}\right)\right\rangle \times \\
& \left\langle-2 \hat{\bar{\rho}} \hat{\Delta}^{2}|\hat{\tilde{S}}|\left(\hat{\tilde{S}}_{i j} \tilde{S}_{i j}-1 / 3 \hat{\tilde{S}}_{m m} \tilde{S}_{j j}\right)\right. \\
& \left.+2 \Delta^{2}\left(\widehat{\bar{\rho}|\tilde{S}| \tilde{S}_{i j}} \tilde{S}_{i j}-1 / 3 \widehat{\bar{\rho}|\tilde{S}| \tilde{S}_{m m}} \tilde{S}_{j j}\right)\right\rangle^{-1} \text {, } \\
& C_{I}=\frac{<\widehat{\bar{\rho} \tilde{u}_{i} \tilde{u}_{i}}-\widehat{\bar{\rho} \tilde{\tilde{u}}} \widehat{\bar{\rho}}_{i} \widehat{\tilde{u}}_{i} / \hat{\bar{\rho}}>}{<2 \hat{\bar{\rho}} \hat{\Delta}^{2}|\hat{\tilde{S}}|^{2}-2 \Delta^{2} \widehat{\bar{\rho}|\tilde{S}|^{2}}>},
\end{aligned}
$$


ここで $\tau_{i j}$ および $\mathscr{T}_{i j}$ は直接計算される SGS 応力で, $\mathscr{T}_{j j}-\hat{\tau}_{j j}$ は GS 成分から計算可能な項で構成される. ^は格子幅の 2 倍の幅を持つテストフィルターでフィ ルター化された值であり， $\hat{\Delta}=2 \Delta$ である．また， $<>$ は空間平均を示している. 温度 $T$ および化学種の質量 分率 $Y_{k}$ はスカラー量であるので, 渦拡散によるモデ ル化から以下のように SGS 拡散を与えることができ $ろ^{(8)}$.

$$
q_{j}=-\frac{\bar{\rho} C \Delta^{2}|\tilde{S}|}{P r_{t}} \frac{\partial \tilde{T}}{\partial x_{j}}, \quad d_{k, j}=-\frac{\bar{\rho} C \Delta^{2}|\tilde{S}|}{S c_{k, t}} \frac{\partial \tilde{Y}_{k}}{\partial x_{j}}
$$

ここで $P r_{t}$ および $S c_{k, t}$ はスカラー量輸送の SGS モデ ル ${ }^{(8)}$ から算出される乱流プラントル数, 乱流シュミッ ト数である.

燃焼反応は燃料をデカンとし, $\mathrm{C}_{10} \mathrm{H}_{22}+31 / 2 \mathrm{O}_{2}$ $\rightarrow 11 \mathrm{H}_{2} \mathrm{O}+10 \mathrm{CO}_{2}$ の一段総括反応を用いる. 燃焼反応 速度はアレニウス型の反応速度式で以下のように与え られる。

$$
\begin{aligned}
& \omega_{F}\left(\rho, T, Y_{F}, Y_{O}\right)= \\
& A\left(\rho Y_{F} / W_{F}\right)^{a}\left(\rho Y_{O} / W_{O}\right)^{b} \exp (-E / R T),
\end{aligned}
$$

ここで $\omega_{F}$ は燃料の消費速度であり, 酸化剂, 生成物の 消費および生成速度は量論比から間接的に決定される. $A$ は反応速度定数, $E$ は活性化エネルギ一, $a, b$ は量 論係数に無関係で燃料によって決まる係数である. 高 級炭化水素の上記係数は Westbook らによって与えら れている ${ }^{(10)} . Y_{F}, Y_{O}$ は燃料と酸化剂の質量分率, $W_{F}$, $W_{O}$ は燃料と酸化剤の分子量である. LES では SGS 成 分の影響を燃焼反応に考慮する必要があるので，燃焼 反応の SGS モデルを導入する. SSFRRM ${ }^{(11)(12)}$ (Scale similarity filtered reaction rate model) では SGS 変動を 考慮すると反応速度は以下のように与えられる.

$$
\begin{aligned}
& \bar{\omega}_{F}=\overline{\overline{\omega_{F}\left(\bar{\rho}, \tilde{T}, \tilde{Y}_{F}, \tilde{Y}_{O}\right)}} \\
& +K_{1} \overline{\overline{\omega_{F}\left(\bar{\rho}, \tilde{T}, \tilde{Y}_{F}, \tilde{Y}_{O}\right)}}-K_{1} \overline{\overline{\omega_{F}\left(\overline{\bar{\rho}}, \tilde{\tilde{T}}, \tilde{Y}_{F}, \tilde{Y}_{O}\right)}},
\end{aligned}
$$

ここで $K_{1}$ はモデル定数であり $K_{1}=1.0$ が最適值とされ る. “涳間フィルターを 2 回かけた值である. こは Favreフィルターを 2 回かけた值であり, $\tilde{\tilde{\phi}}=\overline{\rho \tilde{\phi}} / \bar{\rho}$ で 定義される.

2.2 液相の支配方程式液相の支配方程式は DNS およびLES で同一とし, 数多くの液滴を取り扱 うために固気 2 相流を取り扱う基礎研究においては 一般的な方法である Eulerian / Lagrangian 法を用いる (13) (14). 液滴は蒸発過程で球形を保つものとし, 気相 に対する体積なし, 回転なし, 衝突なしを仮定する. 以下の液滴に関する支配方程式群は Miller らの提案に 基づく ${ }^{(15)}$.

$$
\frac{d X_{i}}{d t}=v_{i}
$$

$$
\begin{aligned}
& \frac{d v_{i}}{d t}=\frac{F_{i}}{m_{d}} \quad F_{i}=m_{d}\left(\frac{f_{1}}{\tau_{d}}\right)\left(u_{i}-v_{i}\right), \\
& \frac{d T_{d}}{d t}=\frac{Q+\dot{m}_{d} L_{V}}{m_{d} C_{L}}, \\
& Q=m_{d}\left(\frac{f_{2}}{\tau_{d}}\right)\left(\frac{N u C_{p, G}}{3 P r_{G}}\right)\left(T-T_{d}\right), \\
& \frac{d m_{d}}{d t}=\dot{m}_{d}=-m_{d}\left(\frac{1}{\tau_{d}}\right)\left(\frac{S h}{3 S c_{G}}\right) \ln \left[1+B_{M}\right],
\end{aligned}
$$

$\tau_{d}$ は液滴の応答時間で, $\tau_{d}=\rho_{L} D^{2} / 18 \mu$ で定義され る. 下付き文字 $G$ は気相の值, $L$ は液相の值である ことを示している. $L_{V}$ は燃料液滴の蒸発潜熱, $C_{L}$ は 燃料液滴の比熱, $C_{p, G}$ は燃料蒸気の定圧比熱である. Miller らはこれらの物性値を温度の関数として与えて いる(15).

$f_{1}$ は実験式に基づいた滑り速度と噴出し速度による 抗力の修正係数で,

$$
\begin{aligned}
& f_{1}=\frac{1+0.0545 R e_{d}+0.1 R e_{d}^{1 / 2}\left(1-0.03 R e_{d}\right)}{1+a\left|R e_{b}\right|^{b}}, \\
& a=0.09+0.077 \exp \left(-0.4 R e_{d}\right), \\
& b=0.4+0.77 \exp \left(-0.04 R e_{d}\right),
\end{aligned}
$$

$R e_{d}=\rho_{G} u_{s} D / \mu_{G}$ は滑り速度によるレイノルズ数, $R e_{b}=\rho_{G} u_{b} D / \mu_{G}$ は噴出し速度によるレイノルズ数で ある. 滑り速度は $u_{s}=\left|u_{i}-v_{i}\right|$, 噴出し速度は $\dot{m}_{d}=$ $\pi \rho_{G} D^{2} u_{b}$ の関係式から与えられる. $f_{2}=\beta /\left(e^{\beta}-1\right)$ は蒸発伝熱の補正係数であり, $D^{2}$ 則に液滴の蒸発が 従うとすれば $\beta=-1.5 P r_{G} \tau_{d} \dot{m}_{d} / m_{d}$ は定数となる.

ヌッセルト数とシャーウッド数はレイノルズ数の影 響を考慮して Ranz-Marshall の補正から，Nu=2+ $0.552 \operatorname{Re}_{d}^{1 / 2} \operatorname{Pr}_{G}^{1 / 3}, S h=2+0.552 \operatorname{Re}_{d}^{1 / 2} S c_{G}^{1 / 3}$ として与 えられる. $B_{M}$ はトランスファ数であり, ClausiusClapeyron の関係式から得られる液滴表面における燃 料蒸気の質量分率 $Y_{s f}$ と気相の燃料蒸気の質量分率 $Y_{F}$ から, $B_{M}=\left(Y_{s f}-Y_{F}\right) /\left(1-Y_{s f}\right)$ として与えられる.

以上の支配方程式から次の相間干涉項 $S$ が導かれる.

$$
\begin{aligned}
& S_{\rho}=S_{Y_{F}}=-\sum_{\alpha} \frac{\omega_{\alpha}}{\Delta V} \dot{m}_{d}, \\
& S_{u_{i}}=-\sum_{\alpha} \frac{\omega_{\alpha}}{\Delta V}\left(F_{i}+\dot{m}_{d} v_{i}\right), \\
& S_{T}=-\sum_{\alpha} \frac{\omega_{\alpha}}{\Delta V}\left(v_{i} F_{i}+Q+h_{V, s f} \dot{m}_{d}\right),
\end{aligned}
$$

ここで $h_{V, s f}$ は液滴表面における蒸発液滴のエンタル ピーであり, $h_{V, s f}=C_{p, G} T_{d}+h_{V}^{0}$ で, $h_{V}^{0}$ は燃料蒸気の 標準生成エンタルピーである. 燃料の質量分率の相間 干涉項は質量分率の保存式の次元が質量となっている ので, 液滴の蒸発した質量に等しい. $\Delta V$ はグリッド 
セルの体積であり， $\omega_{\alpha}$ は液滴が隣接する格子点に相 間干涉項を割り付ける重み付け係数である. LES では 気相の物理量はフィルターがかけられており, フィル ターのかかっていない值を直接液相へ補間することは できない.ここでは便宜的に, フィルターをかけた気 相の値を直接用いることとする.

\section{3. 差分化および Dynamic SGS モデルの検証}

先に示したLES で解かれる圧縮性流体の支配方程式 は簡略化されたものであり，実際にはフィルター化を 行うと多くのSGS 項が現れる. しかしながら, 圧縮性 乱流の Dynamic SGS モデルを考案した Moin らによれ ば支配的な SGS 項のみを考慮すれば付加的な SGS 項 は無視できる可能性があり, 高マッハ数の一様等方性 乱流において提案した Dynamic SGS モデルの有効性 を確認している ${ }^{(8)}$. まず，差分化の評価およびモデル の妥当性を示すために, 単相, 非燃焼場の低マッ八数 および高マッ八数の等方性乱流においてDNS と LES の比較を行った.

計算領域は一辺 $3 \mathrm{~cm}$ の立方体で, DNS では格子点 数を $96^{3}$ とし, LES では格子点数を $32^{3}$ とした. 計 算に用いた初期乱流場の特性值を表 1 に示す. 運動 エネルギーの総量を合わせるために, 初期速度場に はフィルターをかけずに用いた．表 1 中, 格子幅と Kolmogrov scale の比 $\Delta x / \eta$ は DNS の場合に対応して おり，LES では格子幅はおよそ Kolmogrov scale の 9 倍に相当する.

表 1 に示される計算条件のうち, マッ八数が非常 に小さい条件 incomp. は CCUP 法 ${ }^{(6)(16)}$ により計算し, マッ八数が十分大きい条件 comp. では，陽的に時間積 分を繰り返す直接計算法によって計算を行う。圧縮性 流体のケースでは, 初期乱流場の速度場を用いて, 内 部エネルギー $e_{t}=p /(\gamma-1)+1 / 2 \rho u_{i} u_{i}$ が一定となる ように初期圧力場および初期温度場を与えた ${ }^{(8)}$.

支配方程式は非圧縮性流体および圧縮性流体の計算 において，いずれも場合も質量保存式，運動量保存式， エネルギー保存式を採用し, 化学種の質量分率保存式 については解かないものとする.

\section{1 非圧樎性流体, 乱流の DNS およびLES 図}

1 は incomp. の場合の (a) $t / \tau_{l}=6.25$ および (b) $t / \tau_{l}=12.5$ におけるDNS と LES のエネルギースペクトルの比較 である. 図中, $\tau_{l}$ はオイラースケールと速度の r.m.s. 值で定義される Eddy turn over time である. ここで， DNS のエネルギースペクトルはLES の結果と比較す るために格子幅の 3 倍のフィルター幅を用いたフィル ターを速度場にかけて算出されている. エネルギース
ペクトルは計算時間が十分長い場合でも DNS と LES でほぼ一致している。

3.2 圧縮性流体，乱流の DNS および LES 図 2 は comp. の場合の $t / \tau_{l}=2.99$ におけるエネルギース ペクトルの比較を行ったものである. 図 2 には速度の Helmholtz 分解 ${ }^{(17)}$ によって得られる速度の非圧縮性成 分 (solenoidal) と圧縮性成分 (dilatational) を示してい る. 圧縮性成分については低波数領域において差異が 見られるが，全体的にDNS とLES でよく一致してい るといえる.

以上のことから, 差分化およびモデルの妥当性を示 すことができた．圧縮性乱流の Dynamic SGS モデル を用いることで, 幅広いマッ八数の流れを計算するこ とができ, 燃焼流のような密度変化の大きな流れに対 応することができると考えられる．以降の噴霧燃焼流 の LES では，ここで用いたモデル化および差分化を 流用するものとする.

Table 1 Characterstics of the turbulence used for validation test.

\begin{tabular}{llllll}
\hline CASE & $R e_{\lambda}$ & $\lambda \mathrm{cm}$ & $\eta \mathrm{cm}$ & $\bar{M}$ & $\Delta x / \eta$ \\
incomp. & 24.5 & 0.11 & 0.011 & 0.001 & 2.92 \\
comp. & 22.9 & 0.11 & 0.012 & 0.229 & 2.82 \\
\hline
\end{tabular}

$R e_{\lambda}$ : Turbulent Reynolds number (Taylor scale), $\lambda$ : Taylor scale, $\eta$ : Kolmogrov scale, $\bar{M}$ : Average Mach number.

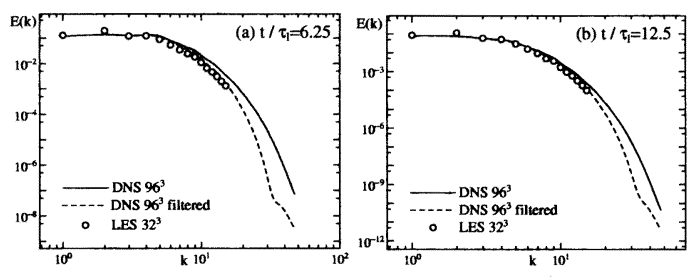

Fig.1 Comparison of energy spectrum in incompressible homogeneous isotropic turbulence at (a) $t / \tau_{l}=6.25$, (b) $t / \tau_{l}=12.5$.

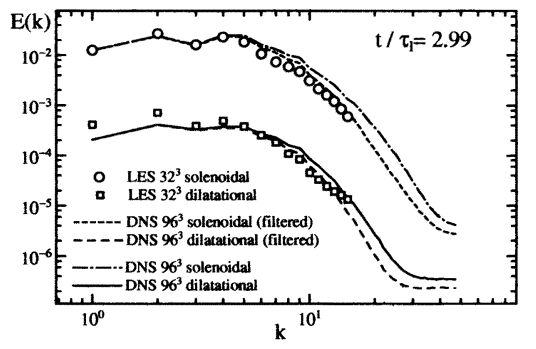

Fig. 2 Comparison of energy spectrum in compressible homogeneous isotropic turbulence at $t / \tau_{l}=2.99$. 


\section{DNS と LES の比較}

4-1 計算条件＼cjkstart単相，非然焼の流れにおいて，差 分化および圧縮性乱流の Dynamics SGS モデルの有効 性を示した。これらの数值解析手法を用いて噴霧燃焼 流の LES を実行し，本稿で提案する相間干渉項の妥当 性を示す．検討を行う計算条件は以下の通りである.

速度場の初期条件は $96^{3}$ の格子点において非压縮性 乱流のDNSにより発達させた発達乱流場を用いる。こ の初期速度場を任意の格子点数の計算格子に補間する にはCIP 法 ${ }^{(16)}$ を用いた. CIP 法で用いる微分值は 4 次 精度中心差分法で算出している．運動エネルギーの総 量を一致させるため, 初期速度場にはフィルターをか けずに初期条件として用いた. 計算領域は一辺 $3 \mathrm{~cm}$ の 立方体である. 液滴は初期条件で $D=40 \mu m$ の均一粒 径とし，乱数によって領域に一様に分布させる. 燃焼 反応は $T_{0}=1000 \mathrm{~K}$ の高温の気体中に液滴を分布させ ることにより，自着火によって引き起こすものとする.

表 2 に計算条件をまとめ, 表 3 には用いた初期乱流 場の特性值を示す．表 2 中，計算条件は一条件につき $\mathrm{a} お よ ひ ゙ \mathrm{~b}$ の 2 種類あり，それぞれ相間干涉項の割付 け方法が異なる. 相間干渉項の割付け方法の詳細につ いては後述する.

計算時間は Itanium2 $(1.6 \mathrm{GHz})$ のワークステーション を用いて最も格子解像度が低いLES32 (a,b) では計算 時間はおよそ 2 時間弱, 最も格子解像度が高いDNS96 (a,b) では計算時間はおよそ 50 時間弱を要した.

Table 2 Resolution and filter width setting.

\begin{tabular}{lllll}
\hline CASE & $N^{3}$ & filter & $\bar{\Delta}$ & $\Delta x / \eta$ \\
\hline DNS32 (a,b) & $32^{3}$ & no & - & 12.36 \\
LES32 (a,b) & $32^{3}$ & yes & 3.0 & 12.36 \\
LES48 (a,b) & $48^{3}$ & yes & 2.0 & 8.245 \\
LES64 (a,b) & $64^{3}$ & yes & 1.5 & 6.184 \\
LES96 (a,b) & $96^{3}$ & yes & 1.0 & 4.122 \\
DNS96 (a,b) & $96^{3}$ & no & - & 4.122 \\
\hline
\end{tabular}

$N^{3}$ : Total number of grid points, $\bar{\Delta}$ : Filter width,

$\Delta x / \eta$ : Spatial interval by Kolmogrov scale.

\section{$4 \cdot 2$ 相間干涉項の割付け方法 反応性および異} 相を伴う流れでは, 相間干渉項の割り付け方法は解像 度の問題と密接に関係する. 図 3 に相間干涉項の割付 け方法の概念図を示す．図3(a) は従来の割付け方法, 図3(b) は本稿で行う割付け方法を示している. 通常は 液滴から気相への相間干涉項 $S_{\rho}, S_{u_{i}}, S_{T}$ および $S_{Y_{k}}$ な どは，図3(a) 中，液滴に隣接する黒丸で表される格子 点のみの割付けられ，その他の格子点には割付けられ ない, 一方, 液滴の支配方程式に現れる気相の物理量,
Table 3 Characteristics of the turbulence used for the initial condition.

\begin{tabular}{llllll}
\hline$R e_{l}$ & $R e_{\lambda}$ & $\lambda \mathrm{cm}$ & $\eta \mathrm{cm}$ & $T_{0} \mathrm{~K}$ & $N_{p}$ \\
114.7 & 41.5 & 0.096 & 0.0076 & 1000 & $10^{4}$ \\
\hline
\end{tabular}

$R e_{l}$ : Turbulent Reynolds number (Euler scale),

$R e_{\lambda}$ : Turbulent Reynolds number (Taylor scale),

$\lambda$ : Taylor scale, $\eta$ : Kolmogrov scale,

$T_{0}$ : Initial temperature, $N_{p}$ : Total number of droplets.

$\rho, u_{i}, T$ および $Y_{k}$ などは相間干渉項を割付けた黒丸 で表される格子点から液滴位置へ割付けられる。気相 の支配方程式中に現れた重み付け係数 $\omega_{\alpha, i}$ は, 液滴 と格子点間の距離 $r r_{i}$ によって次のように与えられる.

$$
\omega_{\alpha, i}=\frac{1 / r r_{i}}{\sum_{i=1}^{8} 1 / r r_{i}}
$$

ここで $\sum_{i=1}^{8} \omega_{\alpha, i}=1$ であり, 添え字 $i$ は液滴に隣接す る格子点に割り振る番号である. 一方, 液滴位置に割 付けられる気相の物理量 $\phi_{p}$ は次のように与えられる.

$$
\phi_{p}=\sum_{i=1}^{8} \omega_{\alpha, i} \phi_{i}
$$

ここで $\phi_{i}$ は液滴を取り囲む格子番号 $i$ の気相の物理量 である.以上が従来の割付け方法である.

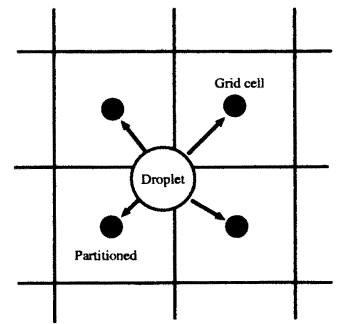

(a) Normal partition

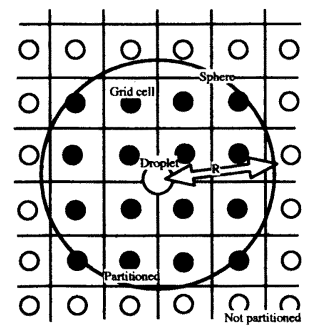

(b) Proposed partition Fig. 3 Schematic of partition of phase coupling terms.

ここで液滴位置で得られる相間干渉項 $S_{\phi}$ を隣接点 のみに割り付けると, 計算結果は解像度によって大き く変化してしまう可能性がある. 本稿ではすべての条 件において, 半径 $R$ の一定体積の球に含まれる格子点 に相間干渉項を割付けることで，割付けに関寸る解像 度の依存性を解消し, 各計算条件が解像度を変化させ ても同一条件となるようにした．本稿ではすべての条 件において次の式を相間干涉項の割付けに用いる.

$$
S_{\phi, i}=\frac{1}{n} S_{\phi, p}, \quad \text { for } \quad i=1 \ldots n,
$$

ここで $S_{\phi, i}$ は半径 $R$ の球に含まれる格子点に割付けら れる相間干渉項, $n$ は半径 $R$ の球に含まれる総格子点 
数, $S_{\phi, p}$ は液滴位置において算出される相間干涉項で ある. 図 3(b) では黒丸で表される格子点へ $S_{\phi, p} / n$ が 等しく割付けられる.

気相の物理量を液滴位置に割付けるには次の 2 通 りの方法を考慮する。従来通り式 (25) に従う場合を

Partition type a とし, 式(25)の代わりに次の式に従っ て気相の物理量を液滴位置に割付ける方法を Partition type b とする.

$$
\phi_{p}=\frac{1}{n} \sum_{i=1}^{n} \phi_{i}
$$

ここで $n$ は半径 $R$ の球に含まれる総格子点数である. すなはち, Partition type b では液滴位置に割付けられ る気相の物理量は, 球内に含まれる気相の物理量の平 均值となる. 球の半径は格子点数 $32^{3}$ の場合の格子点 が少なくとも 8 点含まれるように, LES32 (a,b) の格 子幅 $\Delta x \approx 1 \mathrm{~mm}$ から,$R=1.0 \mathrm{~mm}$ とした.

\subsection{SGS モデル係数の変化 図 4 に渦粘度の係} 数, $C$ と $C_{I}$ の時間変化を示す. Dynamic SGS モデル では同じ乱流場でも渦粘度の係数は格子解像度に依存 して值が変化することが分かる. 特に Smagorinsky モ デルでは $C_{e}=0.2$ が等方性乱流における最適值といわ れているにも関わらず，Dynamic SGS モデルを用いた 場合，值は $C=C_{e}^{2}=0.04$ から大きく変化している. こ こでは $C=C_{e}^{2}=0.04$ となるのは格子点数が $32^{3}$ とな るLES32a およびLES32b の条件である.
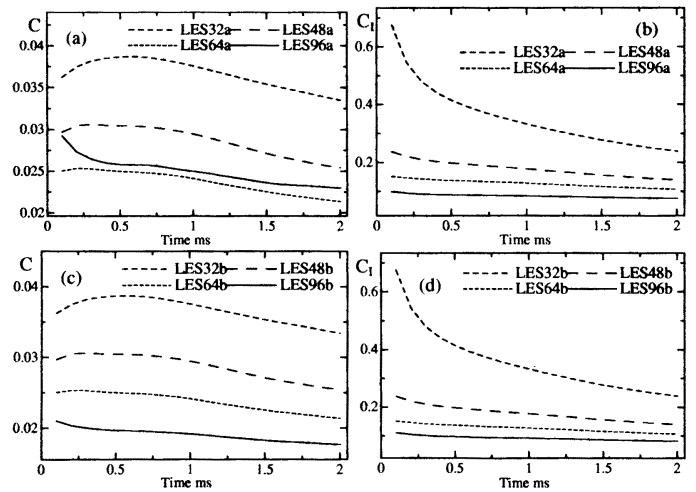

Fig.4 Time variations of eddy viscosity coefficients,

Partition type a, (a) $C$, (b) $C_{I}$,

Partition type b, (c) $C$, (d) $C_{I}$.

図 5 に洞粘度の俰数, $C$ および $C_{I}$ を用いて算出され た渦粘度 $\mu_{S G S}$ および $\mu_{S G S I}$ の時間変化を示す，渦粘度 はそれぞれ $\mu_{S G S}=\bar{\rho} \Delta^{2} C|\tilde{S}|$, および $\mu_{S G S I}=\bar{\rho} \Delta^{2} C_{l}|\tilde{S}|$ にて算出した。.いずれの場合も渦粘度は解像度が上昇 すると一様に減少し，SGS 応力の影響が小さくなって いることが分かる.
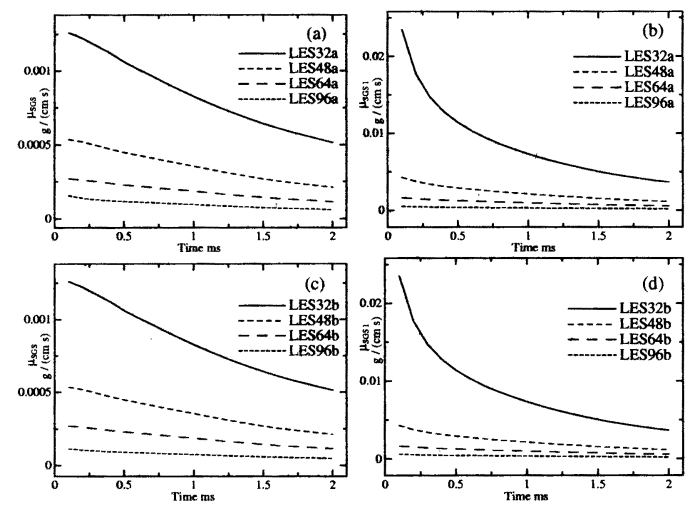

Fig.5 Time variations of eddy viscosities,

Partition type a, (a) $\mu_{S G S}$, (b) $\mu_{S G S I}$,

Partition type b, (c) $\mu_{S G S}$, (d) $\mu_{S G S I}$.

図 6 に乱流プラントル数 $P r_{t}$ と乱流シュミット数 $S c_{t}$ の時間変化を, それぞれ $C / P r_{t}, C / S c_{t}$ にて示す. $S c_{t}$ については 5 種の化学種について平均值をとることで 算出した. 図 6 では格子解像度が高くなるにつれて, SGS 拡散が増加していることが分かる。これは格子 解像度が高い場合には GS 成分の流れ場に小さな構造 が存在し, 液滴運動が細かくなり, 複雑な温度場およ び濃度場が形成されていることに起因している。しか しながら, Partition type b では解像度上昇による SGS 拡散の増加は緩和される. 図 6(d) に示されるように, Partition type b では Partition type a の場合と異なり, 格子解像度が増加しても化学種の SGS 拡散は増加し ない.
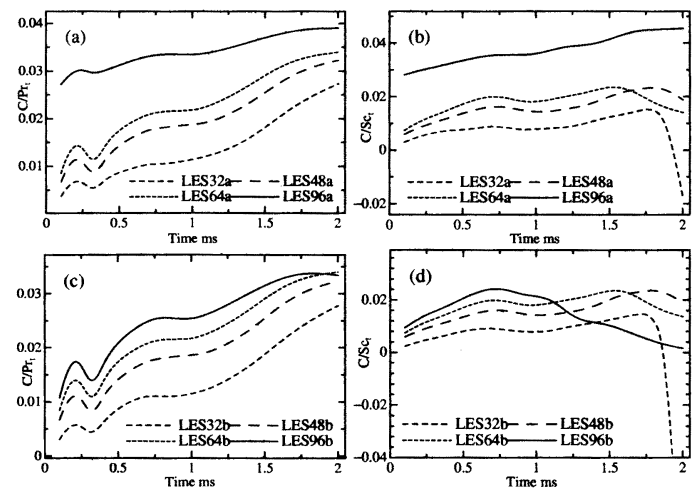

Fig.6 Time variations of SGS model coefficients,

Partition type a, (a) $C / P r_{t}$, (b) $C / S c_{t}$,

Partition type b, (c) $C / P r_{t}$, (d) $C / S c_{t}$.

図 7 に式(13) から算出した温度と燃料蒸気の化学種 質量分率についての SGS 拡散最大值の時間履歴を示 す. 図 7(a), (c) は $\left|q_{\max }\right|$, (b), (d) は然料蒸気につい 
ての $\left|d_{\max }\right|$ を示している. 温度については線は $\left|q_{\max }\right|$, 点は $|q|$ の平均値を示している. 温度については格子 解像度の高さと SGS 拡散の影響の大きさは反比例し ているが, 燃料蒸気については, 格子解像度を上げる と全体的に SGS 拡散が上昇する傾向がある.これは 上記の解像度により GS 成分により細かい分布が現れ るようになることに起因している，また，この場合で も Partition type b の方が格子解像度が高い場合の SGS 拡散の上昇を抑えている.
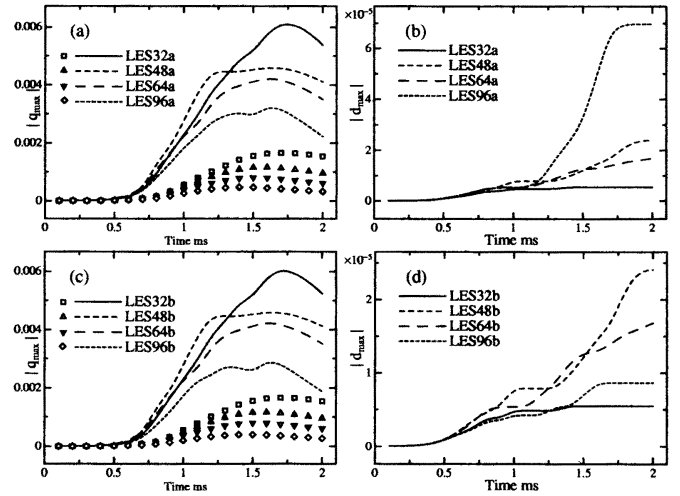

Fig.7 Time variations of maximum SGS diffusivities.

Partition type a: (a) $\left|q_{\max }\right|$, (b) $\left|d_{\max }\right|$,

Partition type b: (c) $\left|q_{\max }\right|$, (d) $\left|d_{\max }\right|$.

4.4 統計量の变化 図 8 に最高温度の時間変化 を示す. 若干のばらつきが見られるものの，すべての 条件で傾向はよく一致している.ただし，LES32aおよ びLES32b は最高温度を低く，LES48a およびLES48b は最高温度を過剩に予測している。この傾向は，温 度場については解像度が不足している DNS32a および DNS32b の条件よりも LES の予測精度が悪化している ことを示し，温度場および濃度場に対するフィルター 化が予測精度を悪化させる可能性があることを示唆し ている. しかし, LES の予測精度は格子解像度が $64^{3}$ 以上に上昇すると向上し，最高温度の変化はDNS の 傾向に近くなる．相間干涉項の割り付け方による差異 を比較すると, Partition type a よりも Partition type b の方が最高温度の差異が大きく，予測精度が悪化する ことが分かる.この他, 平均密度および平均温度の時 間変化はすべての条件でよい一致を見せた.

図 9 に液滴平均粒径の時間変化を示す. 液滴粒径の 変化は液滴数が少数になる計算終了間際で差異が見ら れるが，すべての条件がよく一致する。この他，液滴 総数の時間変化，液相総質量の時間変化はすべての条 件でよく一致した.
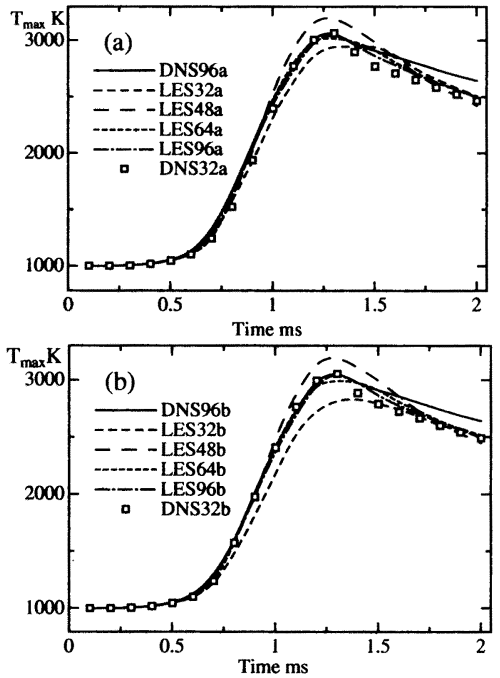

Fig.8 Time variations of maximum temperature.

(a) Partition type a, (b) Partition type b.
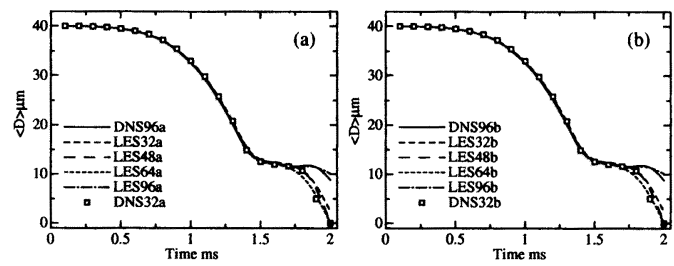

Fig.9 Time variations of mean droplet diameter.

(a) Partition type a, (b) Partition type b.

4.5 エネルギースペクトル＼cjkstart燃焼反応を含めた 場合に乱流場が SGS モデルによって正しく再現されて いるかを確認するために，エネルギースペクトルの比 較を行った．基準とするのは DNS96a および DNS96b の条件であり，LES の結果と比較する際には，対応す る格子幅のフィルターをかけた速度場からエネルギー スペクトルを算出した．対象としたのは然料液滴がす べて蒸発した $2.0 \mathrm{~ms}$ における速度場である.

図 10 および図 11 にDNS と LES のエネルギースペ クトルの比較を示す.エネルギースペクトルは格子解 像度が低い LES32a および LES32b の場合には若干の 差異が見られるが, 格子解像度が高くなるとフィルター をかけていない DNS の結果と LES の結果が一致する ようになる．しかしながら，LES32a およびLES32b は格子解像度が低くてもよくエネルギーカスケードを 再現している. DNS32a およびDNS32b では格子解像 度が足りず, SGS 応力を考虑していないため, エネル ギーカスケードが再現できず，高波数領域においてス ペクトル形状が変形している.

速度場については最高温度に見られたような差異は 
見られず，すべての LES が格子解像度が高いDNS の 結果とよい一致を見せている.

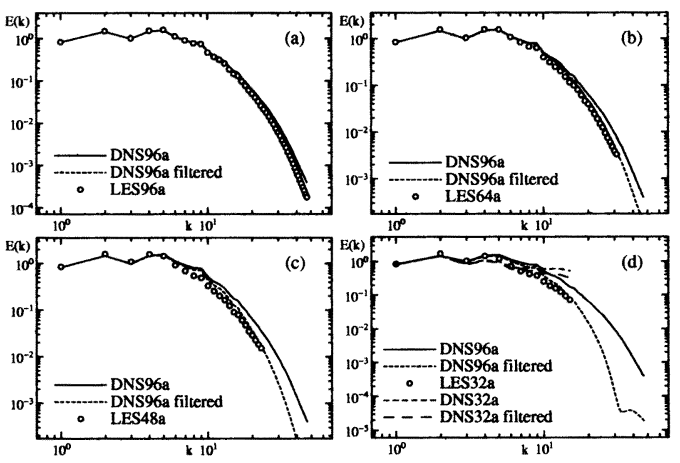

Fig.10 Comparisons of energy spectra between DNS and LES (Partition type a), (a) LES96a, (b) LES64a, (c) LES48a, (d) LES32a

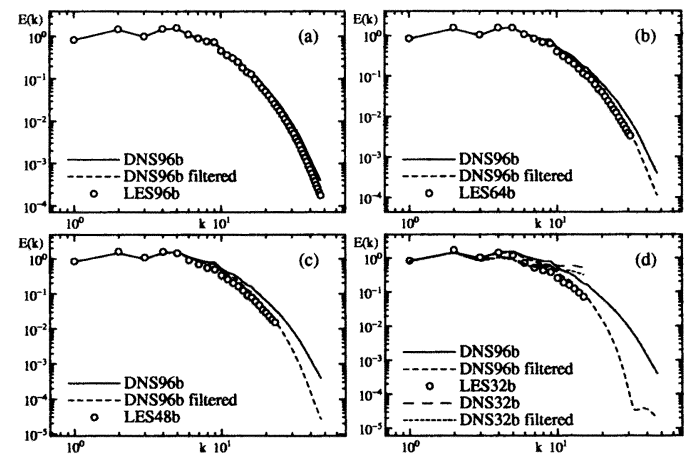

Fig.11 Comparisons of energy spectra between DNS and LES (Partition type b), (a) LES96b, (b) LES64b, (c) LES48b, (d) LES32b

\section{5. 結言}

Dynamic SGS モデルにより，噴霧燃焼流の LES と DNS を等方性乱流において行い, 相間干涉項の割付け 方法およびSGS 成分の影響変化の検討を行った．得 られた知見は以下のとおりである.

1. 本稿で提案した相間干渉項の割付け方法によって, 格子解像度を大きく変更しても LES はす心゙て同 様の傾向を示すことができ，相間干渉項の割付け 方法の妥当性を示すことができた.

2. 格子解像度が上昇すれば SGS 応力の影響は小さ くなる. SGS 応力を考慮しなければ妥当な結果が 得られない強い乱流場において, LESの結果は格 子解像度によらずDNS とよい一致を見せた。
3. 格子解像度が向上すると, 流れ場の複雑な構造が 現れることで液滴運動が細かくなり，SGS 拡散の 影響は SGS 応力の影響に反比例して大きくなる.

4. Partition type bによって解像度上昇に伴う SGS 拡 散の影響の増加を抑えることができるが，必ずし も精度が向上するわけではない. 結果として, 従 来と同じ方法である Partition type a の方がよい結 果を示した.

\section{文献}

(1) Glaze, D.J. and Frankel, S.H., Effect of Dispersion Characteristics on Particle Temperature in an Idealized Non-premixed Reacting Jet, International Journal of Multiphase Flow, 26, (2000), pp.609-633.

(2) Kurose, R. and Makino, M., Large Eddy Simulation of a Solidfuel Jet Flame, Combustion and Flame, 135, (2003), pp.1-16.

(3) Miyauchi, T. et al., Transport Phenomenon in Combustion 2 (Ed.S.H.Chan), Taylor \& Francis, (1996), pp.1095.

(4) Kee, R.J. et al., A Fortran Computer Code Package for Evaluation of Gas-phase Multi-component Transport Properties, Sandia Report, (1986), SAND86-8246.

(5) Kee, R.J. et al., A Fortran Chemical Kinetics Package for the Analysis of Gas Phase Chemical Kinetics, Sandia Report, (1989), SAND89-8009B.

(6) Baba, Y. et al., CIP Characteristics in Direct Numerical Simulations, JSME International Jorunal, Series B, 47, (2004), pp.750-760.

(7) Morinishi, Y. et al., Fully Conservative Higher Order Finite Difference Schemes for Incompressible Flow, Journal of Computational Physics, 143, (1998), pp.90-124.

(8) Moin, P. et al., A Dynamic Subgrid-scale Model for Compressible Turbulence and Scalar Transport, Physics of Fluid, A3(11), (1991), pp.2746-2757.

(9) Germano, M. et al., A Dynamic Subgrid-scale Eddy Viscosity Model, Physics of Fluid, A3(7), (1991), pp.1760-1765.

(10) Westbook, C.K. and Dryer, F.L., Chemical Kinetic Modeling of Hydrocarbon Combustion, Progress in Energy and Combustion Science, 10, (1984), pp.1-57.

(11) DesJardin, P.E. and Frankel, S.H., Large Eddy Simulation of a Nonpremixed Reacting Jet: Application and Assesment of Subgrid-scale Combustion Models, Physics of Fluid, 10, (1998), pp.2298-2314.

(12) Kurose, R. et al., Large Eddy Simulation of a Non-premixed Turbulent Reacting Mixing Layer: Effect of Heat Release and Spanwise Fluid Shear, Combustion and Flame, 127, (2001), pp.2157-2163.

(13) Miller, R.S., Effects of Nonreacting Solid Particle and Liquid Droplet Loading on an Exothermic Reacting Mixing Layer, Physics of Fluid, 13, (2001), pp.3303-3320.

(14) Mashayak, F., Numerical Investigation of Reacting Droplets in Homogeneous Shear Turbulence, Journal of Fluid Mechanics, 405, (2000), pp.1-36.

(15) Miller, R.S. et al., Evaluation of Equilibrium and Non-equilibrium Evaporation Models for Many-droplet Gas-liquid Simulations, International Journal of Multiphase Flow, 24, (1998), pp.10251055.

(16) Yabe, T. et al., The Constrained Interpolation Profile Method for Multiphase Analysis, Journal of Computatinal Physics, 169, (2001), pp.556-593.

(17) Miyauchi, T. et al., Outflow Boundary Conditions for DIrect Numerical Simulation of Compressible Flows, Transaction of the Japan Society of Mechanical Engineers, Series B, 65-630, (1999), pp.528-535. 